\title{
EFEKTIVITAS SISTEM LAHAN BASAH BUATAN DALAM PENGOLAHAN LIMBAH CAIR RUMAH SAKIT-X (Effectiveness of Artificial Wetland System in Processing Liquid Waste of Hospital-X)
}

\section{Atieka Wulandari ${ }^{1}$, Rossie Wiedya Nusantara ${ }^{2}$, dan Muhammad Sofwan Anwari ${ }^{3}$}

\author{
${ }^{1}$ Program Studi Magister Ilmu Lingkungan, Program Pasca Sarjana Universitas Tanjungpura, \\ Jln. Prof. Dr. H. Hadari Nawawi, Pontianak, Kalimantan Barat, 78121. \\ ${ }^{2}$ Program Studi Ilmu Tanah, Fakultas Pertanian, Universitas Tanjungpura, \\ Jln. Prof. Dr. H. Hadari Nawawi, Pontianak, Kalimantan Barat, 78121. \\ ${ }^{3}$ Program Studi Kehutanan, Fakultas Kehutanan, Universitas Tanjungpura, \\ Jln. Prof. Dr. H. Hadari Nawawi, Pontianak, Kalimantan Barat, 78121.
}

*Penulis korespondensi. Tel: 085386069018. Email: atiekawulandari.mil@student.untan.ac.id.

Diterima: 13 Desember 2019

Disetujui: 9 Februari 2020

\begin{abstract}
Abstrak
Lahan basah buatan adalah sistem yang melibatkan tanaman, tanah, mikroba sebagai pengolahan limbah cair. Penelitian ini bertujuan untuk mengkaji efektifitas sistem lahan basah buatan dalam pengolahan limbah cair rumah sakit $\mathrm{X}$ dan mengkaji kemampuan jenis tanaman Canna Indica, Echinodorus palaefolius dan Iris pseudoacorus sebagai biofilter limbah cair rumah sakit X . Lahan basah buatan dibuat menggunakan media pasir, karbon aktif, dan kerikil dalam skala laboratorium. Analisis data menggunakan uji Anova dan Uji BNT dengan penggunaan jenis tanaman sebagai perlakuan biofilter, yaitu Canna Indica, Echinodorus palaefolius plant, Iris pseudoacorus, penggabungan ketiga tanaman, dan tidak ada tanaman sebagai kontrol. Waktu detensi 3, 6, dan 9 hari sebagai perlakuan hari dengan tiga kali ulangan. Parameter utama adalah Biological Oxygen Demand (BOD), Chemical Oxygen Demand (COD), dan amoniak. Parameter pendukung warna, bau, suhu, dan $\mathrm{pH}$. Lahan basah buatan terbukti efektif dalam pengolahan limbah cair rumah sakit $\mathrm{X}$ dan ada perlakuan yang memberikan pengaruh beda nyata terhadap perubahan kualitas air limbah. Hasil penelitian menunjukkan efisiensi penurunan BOD dan COD terjadi pada waktu detensi 6 hari. Variasi waktu berpengaruh terhadap penurunan konsentrasi BOD dan COD. Penggabungan ketiga tanaman (C. Indica, E. palaefolius dan I. pseudoacorus) terbukti efektif sebagai biofilter dalam penurunan parameter $\mathrm{pH}(11,2 \%)$ dan warna $(27,4 \%)$, serta tanaman Echinodorus palaefolius terbukti efektif sebagai biofilter dalam penurunan parameter amoniak (34\%), namun pengggunaan tanaman (biofilter) dalam lahan basah buatan tidak terbukti efektif pada penurunan BOD, COD, dan suhu. Hasil penelitian ini telah memenuhi persyaratan yang ditetapkan oleh Permen KLHK No: $P$. 68/Menlhk/Setjen/Kum.1/8/2016 tentang Baku mutu air Limbah domestik.
\end{abstract}

Kata kunci: lahan basah buatan, BOD, COD, amoniak, limbah cair, limbah rumah sakit.

\begin{abstract}
An artificial wetland is a system which involves plants, soil, and microbes in the wastewater treatment. This research aims to examine the effectiveness of artificial wetland to be used for the hospital's wastewater treatment. It also reviews the role of Canna Indica, Echinodorus palaefolius, and Iris pseudoacorus to serve as biofilters of the hospital's wastewater. The artificial wetland is made of sand, active carbon, and gravels in lab-scale amount. The data was analysed by using Anova test and BNT test. The analysis involved several types of plants serving as a biofilter treatment, namely Canna Indica, Echinodurus palaefolius, Iris pseudoacorus, and the combination of these three plants. None served as a control plant. The detention times were 3, 6, and 9 days compounded with three-time repetitions. The main parameters were Biological Oxygen Demand (BOD), Chemical Oxygen Demand (COD), and amoniak. Supporing parameters included colour, odor, temperature, and $\mathrm{pH}$. The artificial wetland was considered effective in the hospital's wastewater treatment. The results also documented that some treatments had a significantly different effect towards the change of wastewater quality. The research indicated that the efficiency of BOD's and $C O D$ 's decline occured at 6 days of detention. The variety of time affected the concetration decline of BOD and COD. The combination of three plants (E. palaefolius, I. pseudoacorus, and C. Indica) was proven effective as a biofilter which reduces pH parameter (11,2\%) and colour parameter (27,4\%). In addition, The Echinodorus palaefolius plant was reported effective to reduce amoniak parameter (34\%). However, the use of plants (biofilter) in the artificial wetland was not effective towards the decline of BOD, COD, and temperature. The results of this research therefore have met the requirement stipulated by the Goverment regulation of KLHK (Ministry of Environment and Forestry) No: P.68/Menlhk/Setjen/Kum.1/8/2016 on the quality standards of the domestic wastewater.
\end{abstract}

Keywords: artificial wetland, BOD, COD, ammonia, wastewater, hospital waste. 


\section{PENDAHULUAN}

Rumah sakit X merupakan rumah sakit yang memiliki Instalasi Pengolahan Air Limbah (IPAL) dengan sistem anaerob dan aerob. Berdasarkan hasil pemantauan yang dilakukan pihak rumah sakit $\mathrm{X}$ bahwa kualitas air limbah yang dihasilkan masih melebihi baku mutu lingkungan berdasarkan Permen LHK Nomor: P.68/Menlhk/Setjen/ Kum.1/8/2016 tentang Baku Mutu Air Limbah Domestik, untuk parameter Biological Oxygen Demand (BOD) sebesar $89 \mathrm{mg} / \mathrm{L}$, Chemical Oxygen Demand (COD) sebesar $137 \mathrm{mg} / \mathrm{L}$ dan amoniak sebesar 10,4 mg/L, serta air limbah yang dihasilkan masih berbau dan berwarna. Limbah cair rumah sakit dengan kandungan organik tinggi dapat menyebabkan terjadinya pencemaran lingkungan. Karakteristik air limbah organik tinggi dapat ditunjukkan dengan tingginya parameter BOD dan COD dalam air limbah. Berdasarkan Kerubun (2014) bahwa kandungan BOD dan COD yang tinggi dapat menyebabkan penurunan kandungan oksigen terlarut di perairan. Amoniak bersifat racun bagi mayoritas ikan dan teroksidasi secara biologis oleh mikroorganisme menjadi nitrit yang berbahaya bagi manusia (Putri dkk, 2017). Oleh karena itu perlu dilakukan pengolahan limbah yang baik agar tidak mencemari lingkungan dan sesuai dengan baku mutu yang ada.

Mengingat karakteristik air limbah rumah sakit banyak mengandung bahan organik, maka sistem pengolahan limbah secara biologis dapat dijadikan alternatif. Salah satu alternatif sistem pengolahan air limbah tersebut adalah sistem lahan basah buatan. Pengolahan limbah cair rumah sakit menggunakan lahan basah buatan efektif untuk diterapkan karena dapat memanfaatkan proses alamiah yang melibatkan tumbuhan, tanah, dan mikroba yang saling berhubungan untuk membantu pengolahan limbah cair dan berdasarkan Prawira (2015) lahan basah buatan dapat memberikan pengaruh yang baik dalam proses pengolahan limbah karena mencontoh proses penjernihan air yang terjadi di lahan basah atau rawa dan merupakan salah satu teknologi pengolahan limbah yang murah dari segi ekonomi, mudah desainnya juga mudah perawatannya, tetapi mampu menguraikan polutan yang dikandung oleh limbah (Made dan Sugito, 2013).

Proses penurunan bahan organik dalam air limbah rumah sakit dikarenakan peranan tanaman, di mana lahan basah buatan mampu menurunkan parameter COD dengan menggabungkan tanaman melati air dan karbon aktif. Hal ini sejalan dengan Sasono dan Pungut (2013) bahwa tanaman air yaitu melati air dan bambu air yang digunakan pada lahan basah buatan sangat efisien dalam menurunkan kandungan BOD dan COD pada air limbah UPT Puskesmas Janti Kota Malang.

Pengelolaan lahan basah buatan bertujuan supaya limbah cair tidak berbahaya saat dilepas ke lingkungan. Kelayakan air limbah untuk dilepas tersebut mengacu pada baku mutu lingkungan yang ditetapkan oleh Peraturan Menteri Lingkungan Hidup dan Kehutanan Republik Indonesia Nomor : P. 68/Menlhk/Setjen/Kum. 1/8/2016 tentang Baku mutu air Limbah domestik.

Sehubungan dengan hal tersebut, maka perlu dilakukan pengolahan alternatif dengan sistem lahan basah buatan agar dapat mengkaji efektifitas sistem lahan basah buatan dalam pengolahan limbah cair rumah sakit $\mathrm{X}$ dan mengkaji kemampuan jenis tanaman tasbih (Canna indica), melati air (Echinodorus palaefolius) dan Iris (Iris pseudoacorus) sebagai biofilter dalam sistem lahan basah buatan.

\section{METODE PENELITIAN}

\section{Waktu dan Lokasi}

Waktu penelitian dilaksanakan pada bulan Februari-Juni 2019. Lokasi pengambilan sampel air limbah dilaksanakan di Rumah Sakit X, yang berlokasi di pusat Kota Pontianak. Analisis sampel parameter BOD, COD, amoniak, $\mathrm{pH}$, warna dan suhu dilaksanakan di unit laboratorium kesehatan Pontianak serta parameter bau dengan cara membandingkan kondisi fisik air limbah.

\section{Bahan dan Alat}

Bahan yang digunakan pada penelitian merupakan faktor penting di dalam lahan basah buatan. Bahan penelitian dapat dilihat pada Tabel 1 .

Alat penelitian yang digunakan yaitu dengan membuat 5 buah reaktor lahan basah buatan yang kedap air dan dibuat dari akuarium kaca, berbentuk persegi panjang dengan ukuran sesuai dengan debit air limbah yang akan diolah dengan perbandingan ukuran minimal adalah panjang : lebar $=3: 1$ (Sasono dan Pungut, 2013), dikarenakan luasan dimensi akuarium yang sangat besar, maka reaktor lahan basah buatan yang akan digunakan sebagai penelitian, menggunakan skala laboratorium dengan skala 1 : 400. Masing-masing reaktor menggunakan jenis tanaman yang berbeda yaitu tanaman $E$. palaefolius, $C$. indica, dan $I$. pseudoacorus, reaktor penggabungan ketiga jenis tanaman dan reaktor kontrol tanpa menggunakan tanaman. Reaktor lahan basah buatan dapat dilihat pada Gambar 1. 
Tabel 1. Keterangan bahan penelitian.

\begin{tabular}{|c|c|c|c|}
\hline No & Bahan & Jumlah & Keterangan \\
\hline 1. & $\begin{array}{l}\text { Air limbah Rumah Sakit } \\
\text { X }\end{array}$ & 50 liter per akuarium & Debit air limbah 50 liter \\
\hline 2. & $\begin{array}{l}\text { Tanaman melati air }(E . \\
\text { palaefolius) }\end{array}$ & $\begin{array}{l}10 \text { rumpun per } \\
\text { akuarium }\end{array}$ & $\begin{array}{l}\text { Tinggi tanaman masing-masing } 50 \mathrm{~cm} \text {, dengan jarak } \\
\text { antar tanaman } 10 \mathrm{~cm}\end{array}$ \\
\hline 3. & $\begin{array}{l}\text { Tanaman tasbih }(C . \\
\text { indica })\end{array}$ & $\begin{array}{l}10 \text { rumpun } \\
\text { akuarium }\end{array}$ & $\begin{array}{l}\text { Tinggi tanaman masing-masing } 50 \mathrm{~cm} \text {, dengan jarak } \\
\text { antar tanaman } 10 \mathrm{~cm}\end{array}$ \\
\hline 4. & $\begin{array}{l}\text { Tanaman iris } \\
\text { pseudoacorus) }\end{array}$ & $\begin{array}{l}10 \text { rumpun } \\
\text { akuarium }\end{array}$ & $\begin{array}{l}\text { Tinggi tanaman masing-masing } 50 \mathrm{~cm} \text {, dengan jarak } \\
\text { antar tanaman } 10 \mathrm{~cm}\end{array}$ \\
\hline 5. & Karbon aktif & $5 \mathrm{~cm}$ per akuarium & $\begin{array}{l}\text { Karbon aktif yang digunakan yaitu karbon aktif yang } \\
\text { telah diaktivasi }\end{array}$ \\
\hline 6. & Pasir & $5 \mathrm{~cm}$ per akuarium & Ukuran pasir $2 \mathrm{~mm}$ \\
\hline 7. & Kerikil & $5 \mathrm{~cm}$ per akuarium & Ukuran kerikil $32 \mathrm{~mm}$ \\
\hline
\end{tabular}

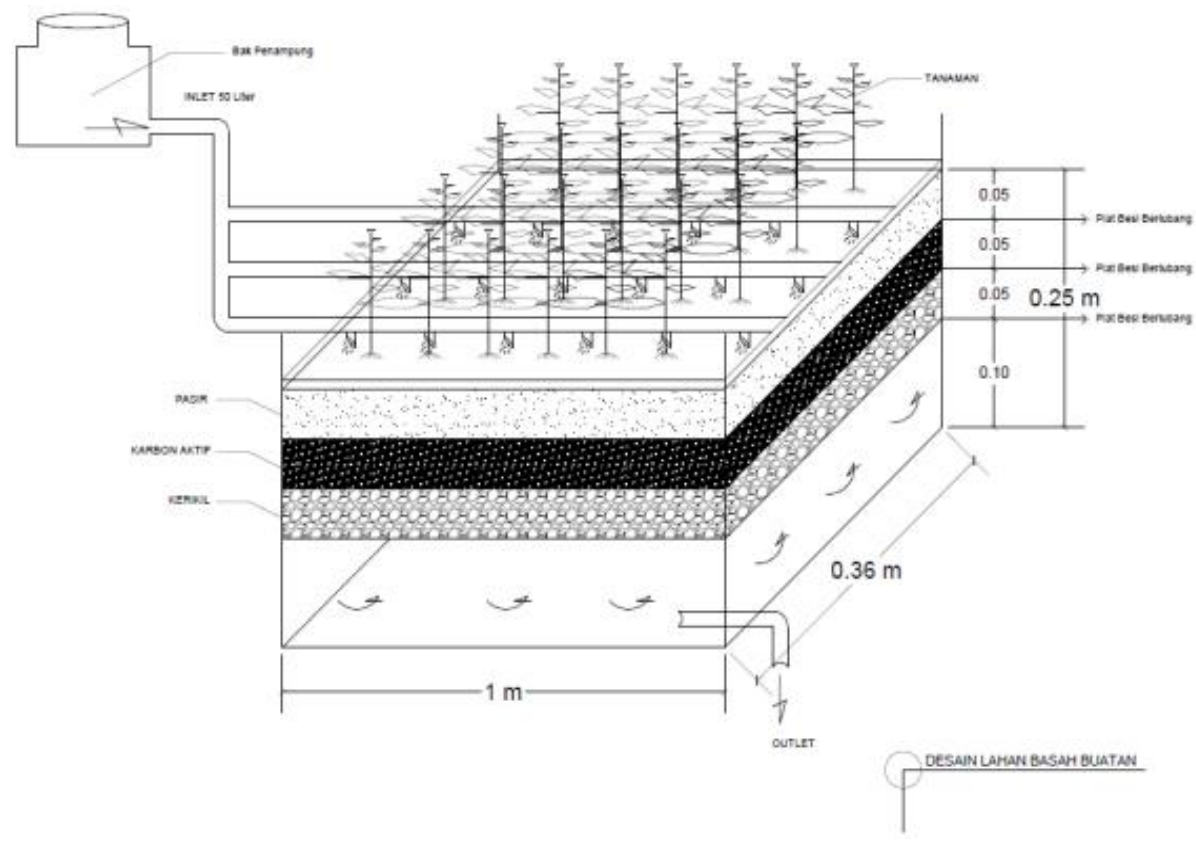

Gambar 1. Reaktor lahan basah buatan.

\section{Prosedur}

Hasil penelitian dianalisis menggunakan uji Anova, yang digunakan untuk melihat pengaruh perlakuan lama hari (waktu detensi) lahan basah buatan terhadap nilai-nilai parameter limbah cair Rumah Sakit X dan pengaruh perlakuan tanaman terhadap nilai-nilai parameter limbah cair Rumah Sakit X. Apabila hasil Anova menunjukkan hasil yang signifikan terhadap nilai-nilai parameter limbah cair Rumah Sakit X, akan dilanjutkan dengan uji BNT dengan selang kepercayaan yang digunakan adalah 5\%. Metode ini menjadikan nilai BNT atau nilai LSD sebagai acuan dalam menentukan apakah rata-rata perlakuan berbeda secara statistik atau tidak. Hasil pengukuran parameter limbah cair Rumah Sakit X setelah diberi perlakuan kemudian dibandingkan dengan Peraturan Menteri Lingkungan Hidup dan Kehutanan Republik Indonesia Nomor : $\mathrm{P}$. 68/Menlhk/Setjen/Kum. 1/8/2016 tentang Baku mutu air Limbah domestik yang diperbolehkan.

\section{HASIL DAN PEMBAHASAN}

\section{Efektifitas Sistem Lahan Basah Buatan Biologycal Oxygen Demand (BOD)}

Rata-rata hasil pengukuran kadar BOD setelah perlakuan pada KO, TM, TC, TI dan PT dapat dilihat pada Gambar 2. Gambar 2 menunjukkan kandungan BOD sebelum dilakukan perlakuan sebesar $377 \mathrm{mg} / \mathrm{L}$, di mana kadar tersebut masih melebihi baku mutu dengan kadar maksimal 30 mg/L. Berdasarkan Doraja dkk, (2012) bahwa limbah yang mengandung bahan organik yang tinggi akan mempunyai nilai BOD yang tinggi. Hasil uji BNT menunjukkan beberapa pasangan waktu penanaman memiliki hasil yang signifikan diantaranya yaitu perbandingan 3 dan 6 hari serta 3 dan 9 hari. Hal ini menunjukkan ada perbedaan nyata penurunan parameter BOD. Namun perbandingan antara 6 dan 9 hari terhadap penurunan parameter BOD tidak signifikan yang berarti tidak berbeda nyata terhadap penurunan parameter BOD. Hal ini sejalan pula dengan 
Arimbi (2017) bahwa perbandingan 6 dan 9 hari terhadap penurunan parameter BOD tidak berbeda nyata.

Pada penelitian ini keberadaan tanaman sebagai biofilter tidak terbukti efektif dalam penurunan kadar BOD limbah cair Rumah Sakit X, namun penurunan BOD yang signifikan disebabkan adanya proses filtrasi, yang terdiri dari pasir, kerikil maupun karbon aktif yang berfungsi sebagai adsorben. Hal ini sejalan dengan Lestari (2012) bahwa kerikil efektif dalam proses pengendapan partikel-partikel terlarut dalam air limbah. Di antara kerikil membentuk rongga yang memungkinkan terjadinya proses sedimentasi, sehingga limbah menjadi relatif lebih jernih. Kerikil juga merupakan tempat yang baik untuk pertumbuhan mikroorganisme dalam menguraikan bahan-bahan organik.

Karbon aktif juga memiliki peranan yang besar dalam penyerapan bahan organik. Berdasarkan Sumarto (2016) bahwa karbon aktif memiliki rongga halus dengan jumlah yang sangat banyak yang berfungsi menyerap apa saja yang kontak dengan karbon aktif tersebut. Karbon aktif secara luas digunakan sebagai adsorben dan secara umum mempunyai kapasitas yang besar untuk mengadsorpsi molekul organik.

Berdasarkan Lestari (2012) pasir juga mampu menurunkan bahan organik dikarenakan pasir merupakan jenis senyawa silika dan oksigen yang ada dalam air berupa koloid yang dapat mengikat $\mathrm{OH}$, pasir juga sebagai tempat menempelnya mikroorganisme. Kemampuan media di dalam adsorpsi tergantung pada waktu detensi air limbah, di mana waktu detensi yang cukup akan memberikan kesempatan kontak antara mikroorganisme dengan air limbah (Suprihatin, 2014). Waktu detensi 6 hari merupakan waktu yang maksimal dalam penurunan kadar BOD, dengan rata-rata penurunan kadar BOD sebesar $22 \mathrm{mg} / \mathrm{L}$ $(94,1 \%)$.

\section{Chemical Oxygen Demand (COD)}

Setelah perlakuan lahan basah buatan pada KO, TM, TC, TI dan PT, maka rata-rata hasil pengukuran kadar COD dapat dilihat pada Gambar 3. Gambar 3 menunjukkan kandungan COD sebelum dilakukan perlakuan yaitu sebesar 580 $\mathrm{mg} / \mathrm{L}$. Setelah melewati lahan basah buatan, kadar COD terus mengalami penurunan yang signifikan.

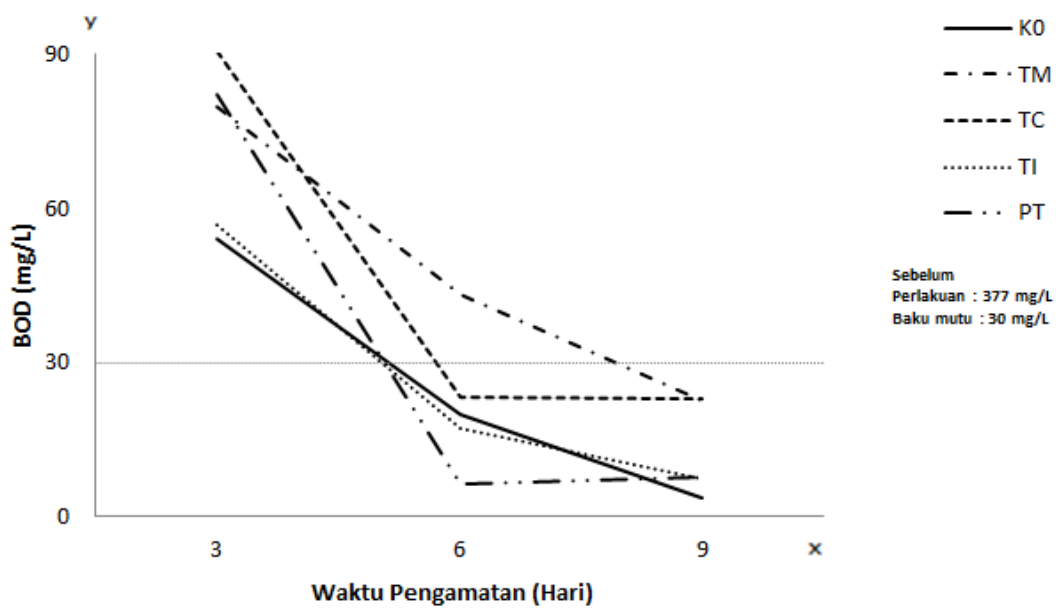

Gambar 2. Rata-rata kadar BOD pada kontrol (KO), tanaman E. palaefolius (tm), tanaman C. indica (tc), dan I. pseudoacorus (ti), serta penggabungan ketiga tanaman (PT).

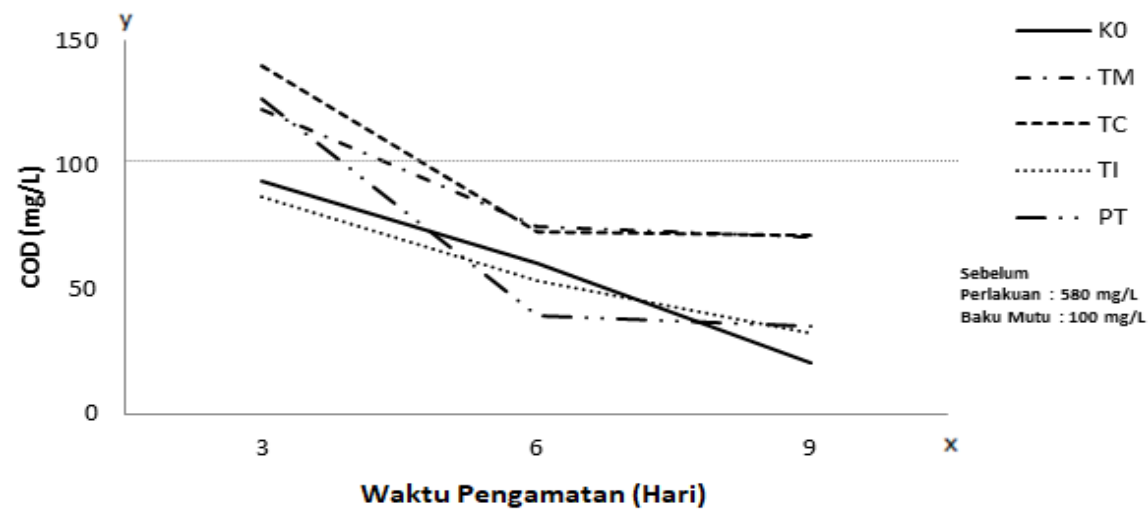

Gambar 3. Rata-rata kadar COD pada kontrol (KO), tanaman E. palaefolius (tm), tanaman C. indica (tc), dan I. pseudoacorus (ti), serta penggabungan ketiga tanaman (PT). 
Penurunan COD juga dapat disebabkan dengan adanya penggunaan karbon aktif tempurung kelapa. Hal ini dibenarkan oleh Alimsyah dan Damayanti (2013) bahwa penurunan COD pada arang tempurung kelapa dikarenakan arang tempurung kelapa mampu mengadsorbsi bahan organik. Sumarto (2016) juga membenarkan bahwa karbon aktif juga memiliki peranan yang besar dalam penyerapan bahan organik karena karbon aktif memiliki rongga halus dengan jumlah yang sangat banyak yang berfungsi menyerap apa saja yang kontak dengan karbon aktif tersebut. Karbon aktif secara luas digunakan sebagai adsorben dan secara umum mempunyai kapasitas yang besar untuk mengadsorpsi molekul organik. Penurunan konsentrasi BOD menunjukkan kecenderungan penurunan pada parameter COD hal ini dibenarkan oleh Arimbi (2017) bahwa penelitian pada lahan basah buatan menunjukkan kecenderungan penurunan konsentrasi COD sejalan dengan penurunan konsentrasi BOD secara bertahap.

Hasil uji BNT menunjukkan beberapa pasangan waktu penanaman memiliki hasil yang signifikan diantaranya yaitu perbandingan 3 dan 6 hari serta 3 dan 9 hari. Hal ini menunjukkan ada perbedaan nyata penurunan parameter COD. Namun perbandingan antara 6 dan 9 hari terhadap penurunan parameter COD tidak signifikan yang berarti tidak adanya perbedaan nyata terhadap penurunan parmeter COD. Hal ini sejalan pula dengan Arimbi (2017) bahwa perbandingan 6 dan 9 hari terhadap penurunan parameter COD tidak berbeda nyata.

Keberadaan tanaman sebagai biofilter pada penelitian ini tidak terbukti efektif dalam penurunan kadar COD limbah cair Rumah Sakit X, namun penurunan COD yang signifikan disebabkan adanya proses filtrasi, yang terjadi pada pasir, kerikil maupun karbon aktif yang berfungsi sebagai adsorben. Hal ini sejalan dengan Lestari (2012) bahwa kerikil efektif dalam proses pengendapan partikel-partikel terlarut dalam air limbah. Di antara kerikil membentuk rongga yang memungkinkan terjadinya proses sedimentasi, sehingga limbah menjadi relatif lebih jernih. Kerikil juga merupakan tempat yang baik untuk pertumbuhan mikroorganisme dalam menguraikan bahan-bahan organik.

Berdasarkan Lestari (2012) pasir juga mampu menurunkan bahan organik dikarenakan pasir merupakan jenis senyawa silika dan oksigen yang ada dalam air berupa koloid yang dapat mengikat $\mathrm{OH}$, pasir juga sebagai tempat menempelnya mikroorganisme. Kemampuan media di dalam adsorpsi tergantung pada waktu detensi air limbah, di mana waktu detensi yang cukup akan memberikan kesempatan kontak antara mikroorganisme dengan air limbah (Suprihatin, 2014). Waktu detensi 6 hari merupakan waktu yang maksimal dalam penurunan kadar COD, dengan rata-rata penurunan kadar COD sebesar $60,4 \mathrm{mg} / \mathrm{L}$ $(89,5 \%)$.

\section{Amoniak}

Rata-rata hasil pengukuran kadar amoniak setelah perlakuan pada KO, TM, TC, TI dan PT dapat dilihat pada Gambar 4. Gambar 4 menunjukkan kandungan amoniak sebelum dilakukan perlakuan atau sampel awal yaitu sebesar $5 \mathrm{mg} / \mathrm{L}$, kemudian setelah dilakukan perlakuan dengan lahan basah buatan parameter amoniak mengalami fluktuatif yang disebabkan beberapa tanaman meranggas dan mati sehingga terdekomposisinya bahan-bahan organik.

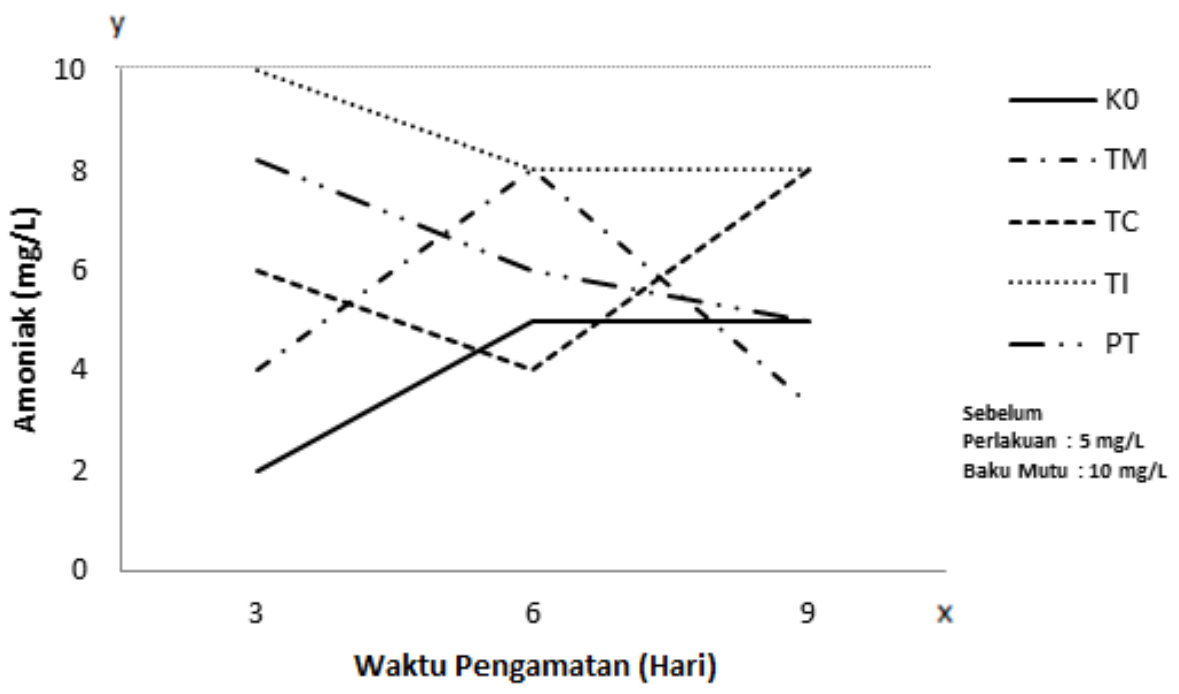

Gambar 4. Rata-rata kadar amoniak pada kontrol (KO), tanaman E. palaefolius (tm), tanaman C. indica (tc), dan I. pseudoacorus (ti), serta penggabungan ketiga tanaman (PT). 
Hal ini dibenarkan oleh Maddusa (2018) bahwa kenaikan amoniak disebabkan karena tidak terserapnya amoniak oleh tanaman karena ada beberapa tanaman yang mati dan membusuk, matinya tanaman mengakibatkan amoknifikasi. Bahan organik yang berada pada limbah akan terurai dengan bantuan mikroba menjadi sumber amoniak baru, namun demikian parameter tersebut masih di bawah baku mutu dengan kadar maksimum yaitu $10 \mathrm{mg} / \mathrm{L}$. Hasil penelitian ini menunjukkan bahwa tanaman E. palaefolius lebih efektif dalam penurunan parameter amoniak dibandingkan jenis tanaman Iris pseudoacorus, tanaman $C$. indica maupun penggabungan ketiga tanaman. Sedangkan bila dibandingkan dengan reaktor kontrol dan tanaman E. palaefolius, reaktor kontrol lebih efektif dalam penurunan parameter amoniak. Menurut Hidayah dkk (2018) bahwa pada reaktor kontrol terdapat mekanisme volatilisasi di mana terjadi proses perubahan amoniak menjadi bentuk gas pada kondisi basa atau $\mathrm{pH}>8$. Sejalan juga oleh Ratnawati dan Talarima (2017) bahwa penurunan amoniak pada air limbah disebabkan oleh volatilisasi kadar amoniak, amonifikasi, imobilisasi sebagai senyawa nitrogen oleh mikroorganisme dan akar tumbuhan. Namun hal ini bertentangan dengan pendapat Hidayah dkk (2018) bahwa lahan basah buatan dengan penggunaan tanaman I. pseudoacorus efektif dalam penyisihan parameter amoniak dibandingkan dengan lahan basah buatan tanpa menggunakan tanaman. Berdasarkan Lestari (2012) bahwa kerikil juga sangat berpengaruh dalam proses pengolahan amoniak, karena di sela-sela kerikil terdapat mikroorganisme yang hidup dan mampu mengurai amoniak. $\mathrm{pH}$ juga sangat berpengaruh terhadap parameter amoniak, semakin basa $\mathrm{pH}$ maka parameter amoniak semakin turun (Retnoningsih dan Murdianti, 2010), di mana $\mathrm{pH}$ pada saat penelitian berkisar antara 9-9,7 (basa). Namun hal ini bertentangan dengan Aka dkk (2017) bahwa semakin rendah kadar amoniak maka akan diikuti oleh penurunan $\mathrm{pH}$ limbah. Dengan demikian biofilter dalam lahan basah buatan terbukti efektif dalam menurunkan amoniak pada limbah cair Rumah Sakit X.

\section{Derajat Kemasaman (pH)}

Rata-rata hasil pengukuran derajat kemasaman $(\mathrm{pH})$ setelah perlakuan pada KO, TM, TC, TI dan PT dapat dilihat pada Gambar 5. Gambar 5 menunjukkan derajat kemasaman $(\mathrm{pH})$ awal sebelum dilakukan lahan basah buatan yaitu 10,14 , derajat kemasaman $(\mathrm{pH})$ ini sangat tinggi disebabkan banyaknya kandungan detergen pada saat pengambilan sampel untuk penelitian.

Hal ini dibenarkan juga oleh Apriyanti dkk (2016) bahwa kenaikan $\mathrm{pH}$ dipengaruhi oleh buangan yang berasal dari zat kimia terlarut dalam air seperti sabun, detergen, shampo dan bahan pembersih lainnya yang berasal dari limbah cucian dapur atau kamar mandi. Limbah cair Rumah Sakit $\mathrm{X}$ juga berasal dari kegiatan laboratorium maupun ruang operasi yang kemungkinan juga dapat menyebabkan naiknya parameter $\mathrm{pH}$, namun setelah dilakukan pengolahan secara lahan basah buatan parameter $\mathrm{pH}$ mengalami penurunan. Efisiensi tertinggi penurunan $\mathrm{pH}$ terjadi pada penggabungan ketiga tanaman, dengan demikian penggunaan biofilter di dalam lahan basah buatan mampu menetralkan konsentrasi $\mathrm{pH}$ pada air limbah domestik khususnya air limbah rumah sakit. Hal ini dibenarkan oleh Hariyanti (2016) bahwa pH sesudah melewati lahan basah buatan hampir mendekati netral, yang disebabkan oleh proses fotosintesis tanaman.

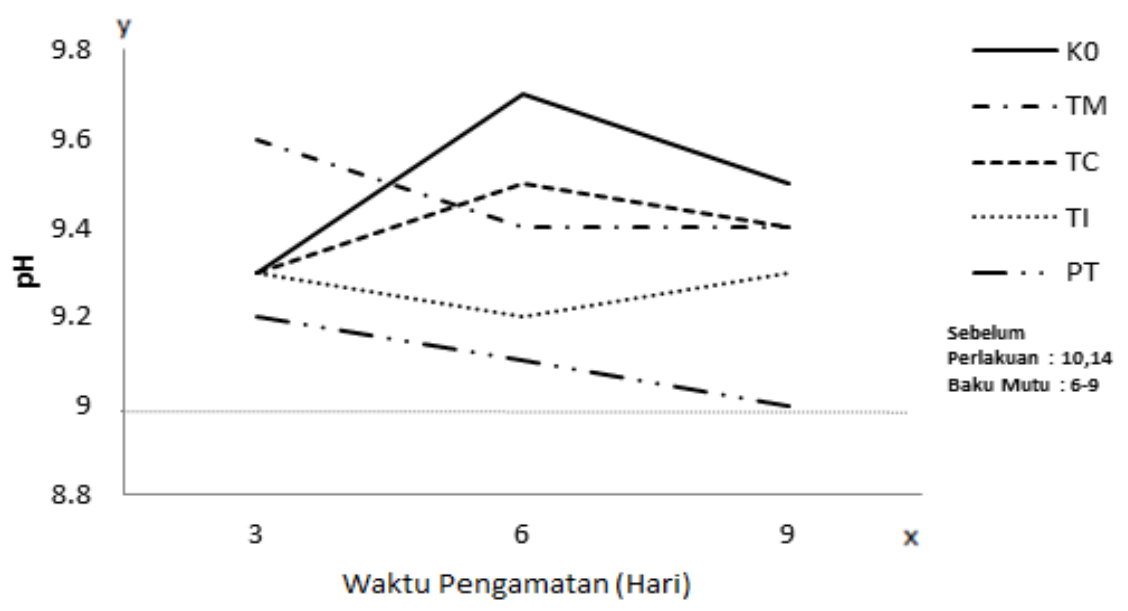

Gambar 5. Rata-rata derajat kemasaman $(\mathrm{pH})$ pada kontrol (KO), tanaman E. palaefolius (tm), tanaman C. indica (tc), dan I. pseudoacorus (ti), serta penggabungan ketiga tanaman (PT). 
Pada penelitian ini $\mathrm{pH}$ outlet yang didapat menurun jika dibandingkan inlet. Hasil yang diharapkan adalah penurunan $\mathrm{pH}$ karena $\mathrm{pH}$ sebelum dilakukan perlakuan sangat basa. Derajat kemasaman $(\mathrm{pH})$ yang sangat basa juga tidak diperbolehkan untuk dibuang langsung ke lingkungan karena dapat mengganggu perairan yang ada. Menurut Lestari (2012) bahwa perairan dengan $\mathrm{pH}$ lebih besar 8,5 (basa) dikategorikan sudah tidak produktif lagi. Proses penurunan $\mathrm{pH}$ juga terjadi karena proses netralisasi dari air limbah yang basa bercampur dengan karbon aktif yang bersifat asam. Proses netralisasi berlangsung semakin meningkat seiring dengan lamanya waktu detensi. Dengan waktu detensi yang cukup, proses netralisasi dapat berlangsung dengan baik dan aktifitas fotosintesis yang dilakukan oleh tanaman juga bisa bekerja dengan baik.

\section{Warna}

Rata-rata hasil pengukuran kadar warna setelah perlakuan pada KO, TM, TC, TI dan PT dapat dilihat dilihat pada Gambar 6. Gambar 6 menunjukkan parameter awal sebelum dilakukan perlakuan pada lahan basah buatan yaitu $332 \mathrm{Pt}$. Co dan setelah melewati lahan basah buatan mengalami peningkatan baik pada kontrol, masingmasing tanaman maupun penggabungan ketiga tanaman. Hal ini disebabkan oleh penggunaan karbon aktif.

Air limbah melewati saringan karbon aktif yang mengalir melewati saringan dan menghasilkan air yang berwarna keruh. Air keruh disebabkan oleh penggunaan karbon aktif yang tidak dilakukan proses pencucian terlebih dahulu sebelum diaplikasikan di dalam lahan basah buatan dan pada saat pengaplikasian terjadi sehingga menyebabkan meningkatnya warna pada air limbah yang diteliti.
Hal ini dibenarkan oleh Sutyasmi dan Susanto (2013) bahwa air limbah hasil pengolahan sistem lahan basah buatan dengan menggunakan arang batok menghasilkan warna keruh dibandingkan air kran walaupun hasil uji mutu air limbah sudah baik namun penggunaan karbon aktif/arang batok sebagai adsorben untuk pengolahan air limbah akan ikut tersuspensi dalam air limbah sehingga air limbah menjadi keruh. Hal ini sependapat pula dengan Roesiani (2015) bahwa karbon aktif sebelum digunakan dilakukan pencucian terlebih dahulu dengan merendam dan mencucinya terlebih dahulu dengan air, sampai air bekas cuciannya bening, namun demikian karbon aktif tersebut tetap efektif dan tetap dapat bekerja dengan baik yaitu sebagai media adsorben dalam penurunan parameter BOD, COD maupun amoniak. Sumarto (2016) juga melaporkan bahwa karbon aktif secara luas digunakan sebagai adsorben dan secara umum mempunyai kapasitas yang besar untuk mengadsorpsi molekul organik. Warna air limbah pada lahan basah buatan penggunaan tanaman Echinodorus palaefolius plant dan tanaman Canna Indica terus mengalami kenaikkan, hal ini disebabkan oleh terdekomposisinya beberapa tanaman yang mengalami pembusukan. Menurut Djabu dan Kusmantoro (1990) bahwa karakteristik yang mencolok pada air limbah cair adalah warna, yang umumnya disebabkan oleh zat organik dan algae dan apabila bahan-bahan organik mengalami dekomposisi oleh bakteri, maka DO turun sampai nol dan warna berubah menjadi hitam yang disebut dengan septic. Pada kontrol dan tanaman Iris pseudoacorus mengalami penurunan dikarenakan adanya sedimentasi/pengendapan di dalam lahan basah buatan dan tidak adanya dekomposisi dari tanaman.

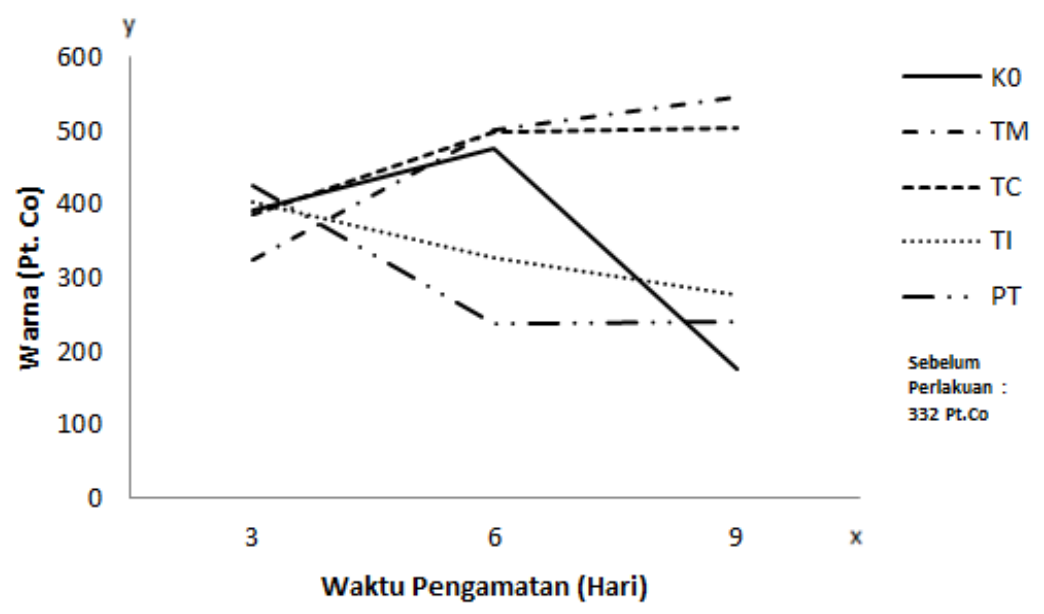

Gambar 6. Rata-rata kadar warna pada kontrol (KO), tanaman E. palaefolius (tm), tanaman C. indica (tc), dan I. pseudoacorus (ti), serta penggabungan ketiga tanaman (PT). 
Selain itu menurut Sugiharto (1987) bahwa warna pada air limbah juga dipengaruhi oleh $\mathrm{pH}$, di mana konsentrasi air limbah yang tidak netral akan menyulitkan proses biologis, sehingga mengganggu proses penjernihannya. Dari berbagai jenis perlakuan tanaman sebagai biofilter, penggabungan tanaman yang paling efektif dalam penurunan kadar warna dengan nilai rata-rata $301.44(9,2 \%)$.

\section{Suhu}

Rata- rata hasil pengukuran suhu setelah perlakuan pada KO, TM, TC, TI dan PT dapat dilihat dilihat pada Gambar 7. Gambar 7 menunjukkan parameter suhu sebelum dilakukan perlakuan atau sampel awal yaitu sebesar $23,8{ }^{\circ} \mathrm{C}$, kemudian setelah dilakukan perlakuan dengan lahan basah buatan mengalami fluktuatif, walaupun mengalami kenaikan suhu pada saat setelah melalui lahan basah buatan namun parameter tersebut masih sangat jauh dari baku mutu, dengan kadar maksimal $38{ }^{\circ} \mathrm{C}$. Menurut Prawira (2015) bahwa tingginya temperatur/suhu salah satunya dapat disebabkan oleh pengaruh cuaca, pengaruh kimia dalam limbah cair dan kondisi bahan yang dibuang ke dalam saluran limbah sejalan juga dengan Made dan Sugito (2013) bahwa pengoperasian lahan basah buatan tergantung pada kondisi lingkungan termasuk iklim dan suhu, di mana pengolahan dengan lahan basah buatan kurang optimal pada suhu yang rendah. Menurut Adisuasono dkk (2014) bahwa bakteri yang tumbuh melakukan penyesuaian diri terhadap suhu antara $25-26^{\circ} \mathrm{C}$.

Hasil uji BNT menunjukkan perbandingan 3 dan 9 hari berbeda nyata. Namun perbandingan antara 6 dan 9 hari terhadap penurunan parameter suhu tidak signifikan yang berarti tidak adanya perbedaan nyata penurunan kadar suhu. Hal ini sejalan pula dengan Arimbi (2017) bahwa perbandingan 6 dan 9 hari terhadap penurunan parameter suhu tidak berbeda nyata. Dari hasil uji
BNT, maka waktu penanaman selama 9 hari adalah waktu penanaman yang paling efektif dengan kadar suhu $22,9{ }^{\circ} \mathrm{C}(3,69 \%)$. Hal ini sejalan dengan Arimbi (2017) bahwa penurunan parameter suhu terjadi pada hari kesembilan.

\section{Bau}

Limbah cair pada saat awal pengambilan sampel sedikit berbau. Hal ini dikarenakan limbah cair tersebut berasal dari berbagai aktivitas yang ada di Rumah Sakit X baik berasal dari dapur, laundry, ruang operasi, laboratorium dan lain-lain. Limbah cair tersebut belum dilakukan pengolahan sama sekali dan memiliki kandungan busa yang tinggi. Hal ini dikarenakan pada saat pengambilan sampel awal merupakan aktivitas tertinggi di Rumah Sakit X. Menurut Doraja dkk (2012) bahwa limbah domestik yang yang berasal dari kegiatan mencuci, memasak, yang umumnya langsung dibuang ke saluran penampung maupun perairan umum diduga mengandung protein, karbohidrat dan lemak yang tinggi. Protein diketahui merupakan penyebab utama terjadinya bau akibat proses penguraian. Pada pengolahan lahan basah buatan pada hari ketiga baik kontrol, masing-masing tanaman maupun penggabungan ketiga tanaman yang memiliki bau yang menyengat yaitu pada tanaman I. pseudoacorus dan penggunaan ketiga tanaman, kemudian pada hari keenam pada ketiga tanaman bau meningkat seiring dengan naiknya kadar amoniak dan pada hari kesembilan pada tanaman E. palaefolius plant maupun tanaman $C$. Indica tidak memiliki bau sama sekali serta yang memiliki bau yang menyengat yaitu pada tanaman I. pseudoacorus dikarenakan kandungan amoniak yang dihasilkan oleh tanaman I. pseudoacorus sebanyak $8 \mathrm{mg} / \mathrm{L}$, namun demikian kadar tersebut masih di bawah baku mutu, dengan kadar maksimum $10 \mathrm{mg} / \mathrm{L}$.

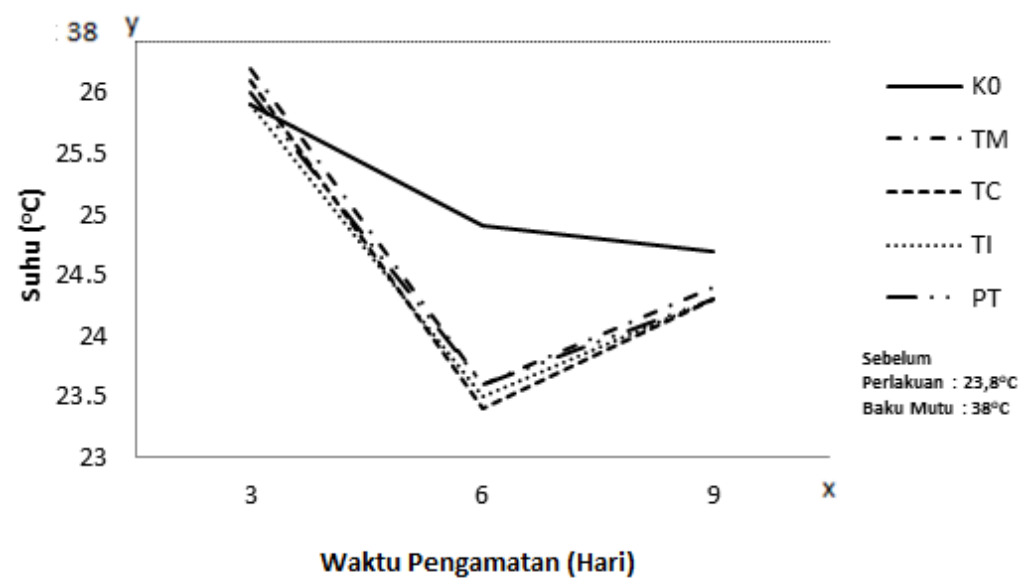

Gambar 7. Rata-rata suhu pada kontrol (KO), tanaman E. palaefolius (tm), tanaman C. indica (tc), dan I. pseudoacorus (ti), serta penggabungan ketiga tanaman (PT). 
Menurut Djohan dan Halim (2013) bahwa bau di dalam limbah cair disebabkan oleh gas-gas hasil dekomposisi zat-zat organik dalam limbah cair, serta ditimbulkan oleh gas $\mathrm{H}_{2} \mathrm{~S}$ (hidrogen sulfida), $\mathrm{NH}_{3}$ (amoniak) dan organik sulfida yang merupakan hasil dekomposisi mikroorganisme anaerob yang mengubah sulfat menjadi sulfida dan protein menjadi amoniak.

\section{Kemampuan Jenis Tanaman Sebagai Biofilter Dalam Lahan Basah Buatan.}

Penggunaan biofilter dalam lahan basah buatan, baik tanaman melati air, iris dan tasbih tidak berpengaruh akan penurunan BOD, COD dan suhu. Hal ini bertentangan dengan Maria dan Winarti (2018) bahwa tanaman tasbih dapat menurunkan kadar BOD dengan efisiensi $93 \%$. Tanpa adanya biofilter (penggunaan tanaman) pada lahan basah buatan kadar BOD, COD dan suhu dapat turun hingga di bawah baku mutu berdasarkan Peraturan Menteri Lingkungan Hidup dan Kehutanan Republik Indonesia Nomor : P. 68/Menlhk/Setjen/Kum. 1/8/2016.

Penggunaan biofilter dalam lahan basah buatan hanya berpengaruh terhadap penurunan amoniak, $\mathrm{pH}$ dan warna, di mana penurunan amoniak terbesar terjadi pada penggunaan tanaman melati air. Tanaman melati air memiliki kemampuan yang cukup baik dalam menurunkan amoniak dengan rata-rata penurunan sebesar 5,11 $\mathrm{mg} / \mathrm{L}$, meskipun tanaman melati air pada hari keenam meranggas/mengalami kematian, namun pada hari kesembilan mulai tumbuh tunas-tunas baru dan masih efektif dalam penurunan polutan dalam limbah cair rumah sakit. Proses penurunan bahan organik dalam air limbah rumah sakit dikarenakan peranan tanaman melati air walaupun pada hari keenam tanaman melati air mengalami kematian namun pada hari kesembilan mulai tumbuh tunas-tunas baru. Hal ini bertentangan dengan Arimbi (2017) bahwa pada hari keenam kondisi tanaman melati air semakin baik ditandai dengan munculnya tunas-tunas baru. Menurut Koesputri dkk (2016) melati air mampu menghisap oksigen dari udara melalui daun, batang dan akar yang kemudian dilepaskan kembali pada daerah sekitar perakaran, oksigen ini nantinya akan digunakan oleh mikroorganisme untuk menguraikan bahan organik yang ada dan melati air memiliki kemampuan yang cukup baik dalam menyerap dan mengurai polutan sehingga menurunkan kandungan polutan itu sendiri karena dipengaruhi oleh beberapa faktor salah satunya sistem perakaran. Sistem perakaran melati air terletak di dasar perairan, reproduksinya fleksibel, kuat, panjang dan menjalar sehingga sangat efektif dalam memperluas area tempat mikroorganisme melekat. Hal ini sependapat pula oleh Ratnawati dan Talarima (2017) bahwa penurunan amoniak terjadi karena akar tumbuhan melati air melakukan imobilisasi polutan dengan cara mengakumulasikan, mengadsoprsi pada permukaan akar dan mengendapkan presipitat polutan dalam zona akar.

Penurunan terbesar $\mathrm{pH}$ dan warna terjadi pada penggabungan ketiga tanaman (melati air + iris + tasbih) sebagai biofilter dalam lahan basah buatan dengan rata-rata penurunan $\mathrm{pH} 9,1$ dan warna 301,44 Pt.Co. Menurut Hutubessy dkk (2012) bahwa tanaman tasbih merupakan salah satu tanaman hias yang potensial untuk menyerap limbah dikarenakan tanaman ini memiliki akar serabut, serta memiliki batang yang mengandung air yang mampu menyerap limbah secara alami. Hidayah dkk (2018) menyampaikan bahwa tanaman iris sangat cocok untuk pengolahan limbah dengan sistem lahan basah buatan dikarenakan memiliki sistem perakaran yang banyak dan cukup kuat untuk menyerap zat organik. Suswati (2012) juga melaporkan bahwa tanaman iris dapat menyerap unsur hara lebih banyak dari yang sebenarnya diperlukan untuk pertumbuhan dan menyimpannya dalam jaringannya dibanding tanaman air lainnya. Menurut Hidayah dkk (2018) bahwa tanaman iris dapat dimanfaatkan untuk pengolahan limbah karena kemampuannya untuk hidup di lingkungan tercemar dan mampu mengangkut dan mentranslokasikan berbagai kontaminan di sekitar perakaran. Penggunaan tanaman sebagai biofilter dalam lahan basah buatan selain dapat menurunkan kadar amoniak, $\mathrm{pH}$ dan warna juga memiliki nilai estetika yang baik.

Berdasarkan beberapa kelebihan yang dimiliki, tanaman sebagai biofilter dapat diaplikasikan sebagai pengolahan limbar cair rumah sakit namun demikian perlu dilakukan perawatan secara rutin/berkala dalam perawatan tanaman, untuk menghindarinya terdekomposisinya daun-daun kering sehingga menimbulkannya amoknifikasi.

\section{KESIMPULAN}

Berdasarkan hasil penelitian dapat diambil kesimpulan bahwa lahan basah buatan terbukti efektif dalam pengolahan limbah cair Rumah Sakit $\mathrm{X}$ dan ada perlakuan yang memberikan pengaruh beda nyata terhadap perubahan kualitas air limbah. Hasil penelitian menunjukkan bahwa efisiensi penurunan BOD dan COD terjadi pada waktu detensi 6 hari. Variasi waktu berpengaruh terhadap penurunan konsentrasi BOD dan COD, semakin lama waktu kontak air limbah di dalam lahan basah 
buatan, maka semakin besar pula efisiensi penurunan BOD dan COD yang dihasilkan sedangkan efisiensi penurunan amoniak tertinggi ditemukan pada perlakuan tanaman E. palaefolius.

Penggabungan ketiga tanaman (E. palaefolius, I. pseudoacorus dan $C$. indica) terbukti efektif sebagai biofilter dalam penurunan parameter $\mathrm{pH}$ $(11,2)$ dan warna $(27,4 \%)$, serta tanaman $E$. palaefolius plant terbukti efektif sebagai biofilter dalam penurunan kadar amoniak (34\%), namun biofilter dalam lahan basah buatan tidak terbukti efektif pada penurunan parameter BOD, COD, dan suhu.

\section{DAFTAR PUSTAKA}

Adisuasono, R.T., Wardana, I.W. dan Sutrisno, E., 2014. Penurunan Konsentrasi Amoniak dalam Limbah Cair Domestik Dengan Teknologi Kolam (Pond)-Biofilm Menggunakan Media Biofilter Pipa PVC Sarang Tawon dan Bata Ringan, Jurnal Teknik. Lingkungan, 3(4):1-12.

Aka, H.A., Suhendrayatna dan Syaubari, 2017. Penurunan Kadar Amonia dalam Limbah Cair oleh Tanaman Air Typha Latifolia (Tanaman Obor). Jurnal Ilmu Kebencanaan, 4(3):72-75.

Alimsyah, A., dan Damayanti, A., 2013. Penggunaan Arang Tempurung Kelapa dan Eceng Gondok untuk Pengolahan Air Limbah Tahu dengan Variasi Konsentrasi, Jurnal Teknik Pomits, 2(1):6-9.

Apriyanti, E., Ihwan, A., dan Jumarang, M.I., 2016. Analisis Kualitas Air Di Parit Besar Sungai Jawi Kota Pontianak, Prisma Fisika, 4(3):101108.

Arimbi, A., 2017. Efektivitas Tanaman Melati Air (Echinodorus Palaefolius) Dalam Menurunkan Kadar BOD (Biologycal Oxygen Demand) dan COD (Chemical Oxygen Demand) serta TSS (Total Suspended Solid) pada Limbah Cair Tempat Pemotongan Ayam di Kecamatan Delitua Kabupaten. Tesis. Universitas Sumatera Utara, Medan.

Djabu, U. dan Kusmantoro, H., 1990. Pembangunan Tinja dan Air Limbah Pada Industri, Jakarta, Pendidikan Tenaga Kesehatan Lingkungan.

Djohan, A.J., dan Halim, D., 2013. Pengelolaan Limbah Rumah Sakit, edited by Aklia Suslia, Salemba Medika, Jakarta.

Doraja, P.H., Maya, S., dan Kuswytasari, N.D., 2012. Biodegradasi Limbah Domestik Dengan Menggunakan Inokulum Alami dari Tangki Septik, Jurnal Sains dan Seni, 1(1):44-47.

Hariyanti, F., 2016. Efektifitas Subsurface FlowWetlands Dengan Tanaman Eceng Gondok dan Kayu Apu dalam Menurunkan Kadar COD dan TSS Pada Limbah Pabrik Saus, Skripsi. Universitas Muhammadiyah Semarang.

Hidayah, E.N., Djalalembah, A., Asmar, G.A., dan Cahyonugroho, O.H., 2018. Pengaruh Aerasi dalam Constructed Wetland Pada Pengolahan Air Limbah Domestik, Jurnal Ilmu Lingkungan, 16(2):155-161.

Hutubessy, J. I. B., Suarna, I.W., dan Astarini, I.A., 2012. Pertumbuhan Tanaman Bunga Kana (Canna Indica L) dalam Menyerap Limbah Deterjen pada Berbagai Jenis Tanah, Ecotrophic, 7(2):156-163.

Kerubun, A.A., 2014. Kualitas Limbah Cair di Rumah Sakit Umum Daerah Tulehu, Jurnal MKMI, 180-185.

Koesputri, A.S., Nurjazuli dan Dangiran, H.L., 2016. Pengaruh Variasi Lama Kontak Tanaman Melati Air (Enchinodorus Palaefolius) dengan Sistem Subsurface Flow Wetlands Terhadap Penurunan Kadar BOD, COD dan Fosfat dalam Limbah Cair Laundry, Jurnal Kesehatan Masyarakat, 4(4):771-779.

Lestari, D.E., Satrianegara, M.F., dan Susilawaty, A., 2013. Efektivitas Pengolahan Limbah Cair Domestik dengan Metode Rawa Buatan (Constructed Wetland). Al-Sihah, 5:184-193.

Maddusa, S.S., 2018. Efektivitas Tanaman Jeringau (Acorus Calamus) untuk Menurunkan Kadar Amoniak Pada Air Limbah RSUD Kota Bitung. Jurnal Kesehatan Masyarakat, 7(1):37-46.

Made, D., dan Sugito, 2016. Penurunan Amoniak dan Phospat Air Limbah Puskesmas Janti Kota Malang Dengan Wetland, J. Teknik Waktu, 11(1):93-101.

Menteri Lingkungan Hidup dan Kehutanan Republik Indonesia., 2016. Peraturan Menteri Lingkungan Hidup dan Kehutanan Republik Indonesia Nomor: P.68/Menlhk-Setjen/2016.

Prawira, J., 2015. Efektifitas Sistem Lahan Basah Buatan Sebagai Alternatif Pengolahan Limbah Domestik Menggunakan Tanaman Hias Iris Pseudoacorus, Tesis. Universitas Maritim Raja Ali Haji.

Putri, A.C., Sulistiyani dan Rahardjo, M., 2017. Efektivitas Penggunaan Karbon Aktif dan Karang Jahe Sebagai Filtrasi Untuk Menurunkan Kadar Amoniak Limbah Cair Rumah Sakit Semen Gresik, Jurnal Kesehatan Masyarakat, 5(5):470-474.

Ratnawati, R., dan Talarima, A., 2017. Subsurface (SSF) Constructed Wetland Untuk Pengolahan Air Limbah Laundry, J. Teknik Waktu, 15:1-6. 
Retnoningsih, M., dan Murdianti, Y., 2010. Pengaruh pH, Konsentrasi Awal Ammonia dan Waktu Operasi Pada Elektrolisa Ammonia, Makalah Seminar Teknik Kimia Universitas Diponegoro, Semarang.

Roesiani, L., 2015. Keefektifan Lama Kontak Karbon Aktif Terhadap Penurunan Kadar Amonia Limbah Cair Industri Tahun di Desa Teguhan Sragen Wetan, Tesis. Universitas Muhammadyah Surakarta.

Sasono, E., dan Pungut, 2013. Penurunan Kadar BOD dan COD Air Limbah UPT Puskesmas Janti Kota Malang Dengan Metode Contructed Wetland, J. Teknik Waktu, 11:60-70.

Sugiharto, 1987. Dasar-dasar Pengelolaan Air Limbah. UI-PRESS, Jakarta.

Sumarto, 2016. Community Engagement Waste Management dengan Activated Carbon (Nano Porus Materials), Bioarang dan Kompos bagi
Masyarakat Desa Parit dan Kebun IX Kec . Sungai Gelam Kab . Mua, Conference ICON UCE, Surabaya 5 Agusuts 2016.

Suprihatin, H., 2014. Wetland dengan Tanaman Hias Bintang Air ( Cyperus alternifolius ), Dinamika Lingkungan Indonesia, 1(2):80-87.

Suswati, A., Wibisono, G., Masrevanlah, A., dan Arfiati, D., 2014. Analisis Luasan Contructed Wetlan Menggunakan Tanaman Iris dalam Mengolah Air Limbah Domestik (Grey Water). Indonesia Green Technology Journal, 1(3):1-7.

Sutyasmi, S., dan Susanto, H.B., 2013. Penggunaan Tanaman Air (Bambu Air dan Melati Air) Pada Pengolahan Air Limbah Penyamakan Kulit Untuk Menurunkan Beban Pencemar dengan Sistem Wetland dan Adsorpsi, Majalah Kulit, Karet \& Plastik, 29(4):69-76. 